ХИВ/АИДС НА ПОДРУЧЈУ БЕОГРАДА ОД 2003. ДО 2012. ГОДИНЕ

${ }^{1}$ Биљана Беговић Вуксановић, ${ }^{2}$ Ивана Беговић Лазаревић, ${ }^{3}$ Андреа Узелац Шкорић, ${ }^{4}$ Славица Марис

\title{
HIV/AIDS IN BELGRADE BETWEEN 2003. AND 2012.
}

Biljana Begović Vuksanović, Ivana Begović Lazarević, Andrea Uzelac Škorić, Slavica Maris

\section{Сажетак}

У раду је приказана епидемиолошка ситуација ХИВ/АИДС-а на подручју Београда од 2003. до 2012. године. Према подацима из пријава заразних болести и годишњих извештаја о раду на спречавану, сузбијању и елиминацији заразних болести у посматраном периоду, ХИВ инфекиија је регистрована код 641 особе, од АИДС-а је оболело 288 особа, а са ХИВ инфекиијом или од АИДС-а је умрло 185 особа. Највише новооткривених инфекиија је регистровано 2009. године (80), највише оболелих и умрлих 2003. године (41, односно 28). Мушкаричи су учесталији од жена међу инфицираним, оболелим и умрлим особама (83,9\%, 76,7\% и 76,2\%). Највећи број инфицираних особа је био од 25 до 29 година (19,8\%), а затим 30-34 године $(18,4 \%)$. Међу оболелим особаманајзаступљенијајегрупа 35-39 и 40-44 године са 16,7\%, односно 16,3\%. Највише особа умрлих са ХИВ-ом или од АИДС-а је у групи 45-49 (20,5\%) и 50-54 године (18,9\%). Међу инфицираним и оболелим особама y посматраном периоду најчешћи начин трансмисије је ризично сексуално понашағе међу хомо/бисексуалцима (53,2\% свих инфицираних, односно 35,4\% оболелих), док је међу особама умрлим са ХИВ-ом или од АИДС-а најодговорнија била интравенска употреба наркотика (43,8\% ). Оно што карактерише епидемију ХИВ/АИДС у Београду у посматраном десетогодишњем периоду је касно откривање инфекиија, односно откривање у фази развијеног АИДС-а.

Кључнеречи: ХИВ, СИДА, ризичнопонашање.

\section{Summary}

This document presents epidemiologic overview of HIV/AIDS in Belgrade between 2003 and 2012. Based on reporting forms and annual reports of prevention, containment and elamination of infectious diseases, there were 641 HIV infected people, 288 AIDS cases and $185 \mathrm{HIV}$ or AIDS related deaths. The most number of HIV infections was registered in 2009 (80), AIDS cases and HIV or AIDS related deaths in 2003 (41 and 28). Men were more frequent than women among HIV infected people as well as among AIDS cases and HIV or AIDS related deaths (83,9\%, 76,7\% $u$ 76,2\%). The majority of all HIV infection registered in Belgrade between 2003 and 2012 were in group of 25-29 years (19,8\%), then 30-34 years $(18,4 \%)$. AIDS cases were the most frequent in group of 35-39 and 40-44 years $(16,7 \%$ and $16,3 \%)$ and HIV or AIDS related deaths in group of 45-49 and 50-54 years $(20,5 \%$ and $18,9 \%)$. The most frequent mode of transmission among HIV infected people $(53,2 \%)$ and AIDS cases $(35,4 \%)$ were homo/biseksual intercourses. Among HIV or AIDS related deaths it was intravenous using of drugs $(43,8 \%)$. HIV/AIDS epidemic in Belgrade, for that ten years period of time, featurs late presentation of HIV infection, with advanced HIV desease.

Key words: HIV, AIDS, risk behaviour.

\footnotetext{
1 Др мед. Биљана Беговић Вуксановић, епидемиолог, Градски завод за јавно здравље Београд.

2 Др мед. Ивана Беговић Лазаревић, епидемиолог, Градски завод за јавно здравље Београд.

${ }^{3}$ Др мед. Андреа Узелац Шкорић, епидемиолог, Градски завод за јавно здравље Београд.

${ }^{4}$ Др мед. Славица Марис, епидемиолог, Градски завод за јавно здравље Београд.
} 
УВОД

$\longrightarrow$

индром стечене имунодефицијенције (на француском „Sуndrome d'Immuno-Deficense Acquise“ - SIDA, ili na engleskom „Acquired Immunodeficience Syndrome“ - AIDS) јесте терминални стадијум хроничне инфекције вирусом хумане имунодефицијенције (,Нuman Immunodeficiency Virus“ - HIV) и први пут је препознат 1981. године, да би врло брзо достигао епидемијске размере и постао један од најзначајнијих проблема света, посебно у земљама Трећег света, где је довео до драматичног скраћења животног века, уз погубни утицај на садашњи и будући економски развој тих, већ и тако сиромашних земаља. У земљама развијеног Запада, у којима је од 1996. године широко доступна високо-активна антиретровирусна терапија („Highly Active Antiretroviral Therapy“ - HAART) регистрован је значајан пад инциденције и морталитета од АИДС-а. Међутим, овај пад је достигао плато који се последњих година одржава, наговештавајући да је и најоптимистичкији сценарио о ефикасности и доступности антиретровирусне терапије још увек далеко од тежњи пацијената и њихових лекара да се са ХИВ-ом „нормално“ живи.

С обзиром на чињеницу да је прво регистрован код хомосексуалаца, затим код интравенских наркомана и код прималаца трансфузија крви пореклом од нетестираних давалаца, као и код хемофиличара, ХИВ/ АИДС се у почетку везивао за тзв. ризичне групе, али се врло брзо, са порастом хетеросексуалног пута преноса уводи термин „ризично понашање“, које је и данас у употреби.

ХИВ је ретровирус. Идентификована су два типа: тип 1 (ХИВ-1) и тип 2 (ХИВ-2). Ова два вируса су серолошки и географски релативно различита, али имају сличне епидемиолошке карактеристике. Тип 1 је патогенији, док је тип 2 генетски сличнији мајмунском вирусу имунодефицијенције (SIV), мање је вирулентан и инфекција спорије прогредира у АИДС. ${ }^{(1)}$
Глобално, процењује се да 35,3 милиона људи живи са ХИВ-ом у 2012. години. Пораст овог броја у односу на претходне године је резултат веће доступности антиретровирусне терапије. У односу на 2001. годину региструје се пад у броју новоинфицираних за 33\%. У исто време број људи умрлих од АИДС-а је такође у паду са 1,6 милиона у 2012. години у односу на 2,3 милиона у 2005. години. ${ }^{(2)}$

\section{ЦИЛ}

Циљ рада је сагледавање епидемиолошке ситуације ХИВ/АИДС-а на подручју Београда од 2003. до 2012. године.

\section{МАТЕРИЈАЛ И МЕТОДЕ}

За анализу епидемиолошке ситуације ХИВ/АИДС-а на подручју Београда коришћени су подаци из пријава заразних болести, медицинске документације, годишњих извештаја о раду на спречавању, сузбијању и елиминацији заразних болести и резултати епидемиолошких и лабораторијских испитивања. Подаци су обрађени путем софтверске апликације израђене у програму Microsoft Access. У обради података примењен је дескриптивни епидемиолошки метод.

\section{РЕЗУЛТАТИ}

У посматраном десетогодишњем периоду, ХИВ инфекција је регистрована код 641 особе, од АИДС-а је оболело 288 особа, a са ХИВ инфекцијом или од АИДС-а је умрло 185 особа. Највише новооткривених инфекција је регистровано 2009. године (80) са инциденцијом од 50/1.000.000, највише оболелих и умрлих 2003. године (41, односно 28) са инциденцијом од $25,6 / 1.000 .000$ и стопом морталитета од 17,5/1.000.000 (Графикон 1 и 2). 
Графикон 1. ХИВ/АИДС на подручју Београда од 2003. до 2012. године, заступьеност по годинама.

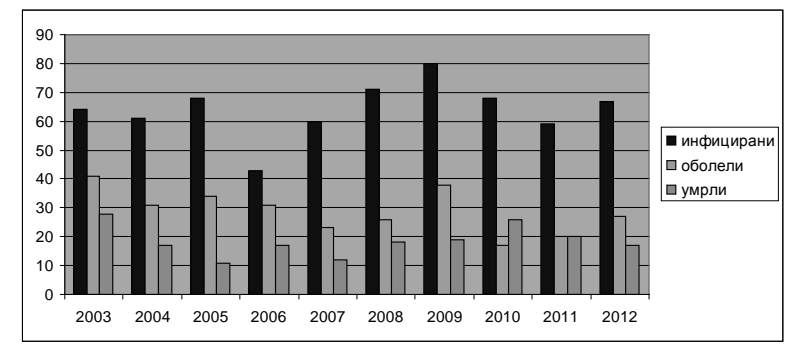

Графикон 2. ХИВ/АИДС на подручју Београда од 2003. до 2012. године, инциденција на 1.000.000 становника.

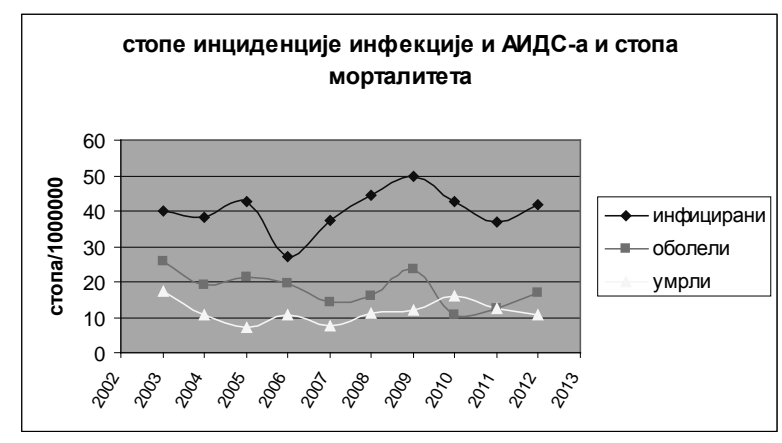

У укупном броју инфицираних, оболелих и умрлих особа у посматраном периоду мушкарци су знатно заступљенији од жена ca $83,9 \%, 76,7 \%$ и 76,2\% (Графикон 3 ).

Графикон 3. ХИВ/АИДС на подручју Београда од 2003. до 2012. године, дистрибуиија по полу.

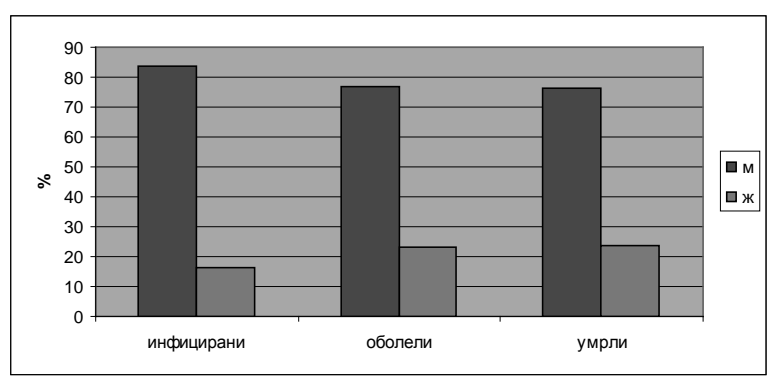

Посматрајући узрасну дистрибуцију инфицираних, оболелих и особа умрлих са ХИВ-ом или од АИДС-а, уочен је највећи број инфицираних особа од 25 до 29 година $(19,8 \%)$, а затим 30-34 године $(18,4 \%)$. Међу оболелим особама најзаступљенија је група 35-39 и 40-44 године са 16,7\%, односно $16,3 \%$. Највише особа умрлих са ХИВ-ом или од АИДС-а је у групи 45-49 и 50-54 године са 20,5\%, односно $18,9 \%$ (Графикон 4).
Графикон 4. ХИВ/АИДС на подручју Београда од 2003. до 2012. године, дистрибуиија по узрасту.

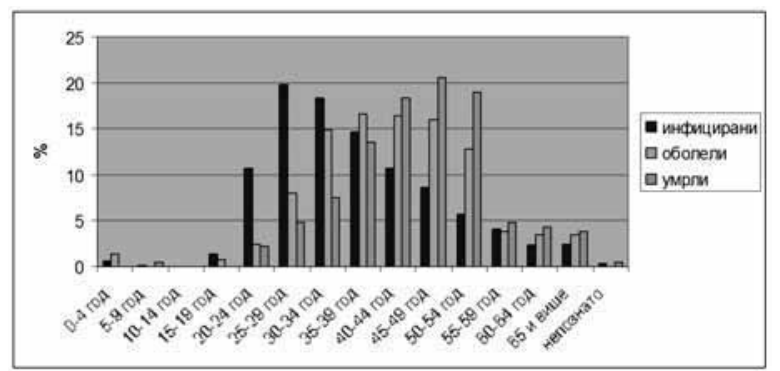

Међу инфицираним и оболелим особама у посматраном периоду најчешћи начин трансмисије је ризично сексуално понашање међу хомо/бисексуалцима (53,2\% свих инфицираних, односно $35,4 \%$ оболелих), док је међу особама умрлим са ХИВ-ом или од АИДС-а најодговорнија за инфекцију била интравенска употреба наркотика $(43,8 \%)$, што је приказано на Графикону 5.

Графикон 5. ХИВ/АИДС на подручју Београда од 2003. до 2012. године, дистрибуиија према начину трансмисије.

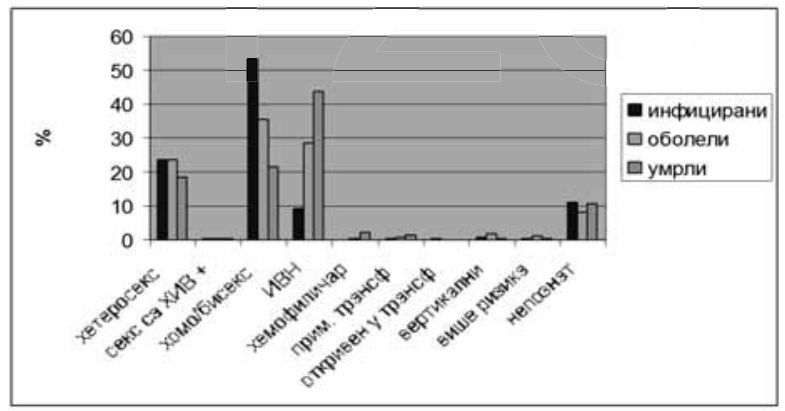

Највећи број инфицираних особа у посматраном периоду је регистрован на подручју општина Палилула - 95 (14,8\%) и Звездара 73 (11,4\%), оболелих на општинама Нови Београд - $44(15,3 \%)$ и Палилула - 40 $(13,9 \%)$, а умрлих особа је највише било на територији општина Нови Београд - 27 $(14,6 \%)$ и Звездара - 25 (13,5\% ), што је приказано на Графикону 6. 
Графикон 6. ХИВ/АИДС на подручју Београда од 2003. до 2012. године, дистрибуиија по опитинама.

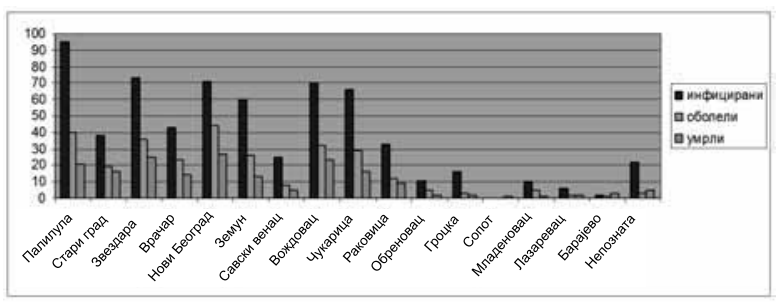

Оно што карактерише епидемију ХИВ/ АИДС у Београду у посматраном десетогодишњем периоду је касно откривање инфекција, односно откривање у фази развијеног АИДС-а. Проценат се креће од $11,7 \%$ 2010. године до чак $48,4 \%$ новооткривених инфекција, које су 2003. године биле регистроване у стадијуму АИДС-а (Графикон 7).

Графикон 7. Проиенат ХИВ инфекиија регистрованих у фази АИДС-а, дистрибуција по годинама.

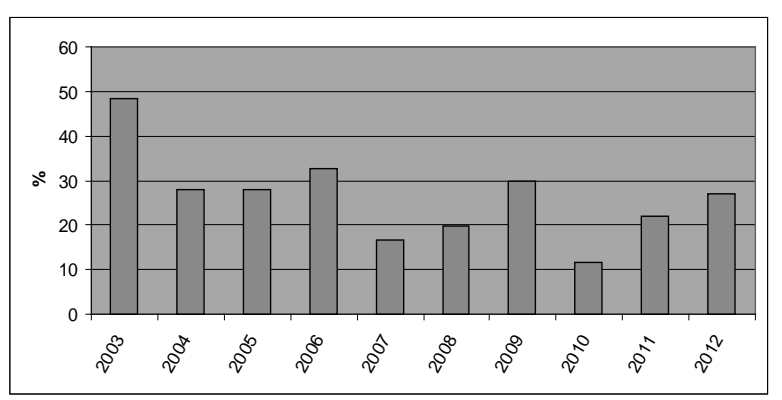

Најзаступљенија манифестација АИДС-а у посматраном периоду је био синдром кахексије $(22,9 \%)$, следи инфекција бацилом туберкулозе $(17,5 \%)$ и пнеумонија коју изазива Pneumocystis carinii $(15,4 \%)$. Малигни тумори грлића материце са $1,2 \%$ су најређе заступљена клиничка манифестација оболелих (Графикон 8).
Графикон 8. Заступљеност клиничких манифестација обољења.

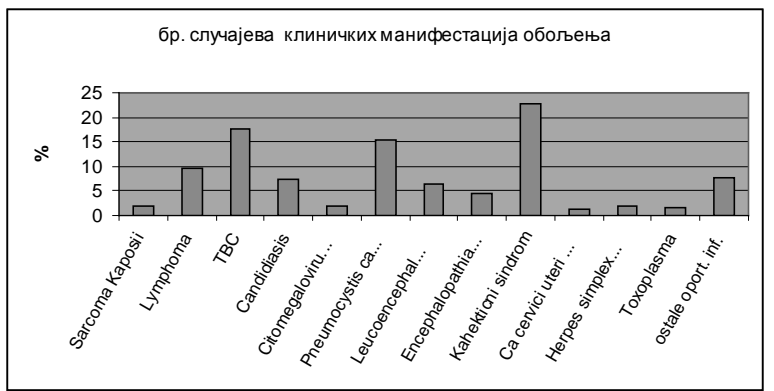

У моменту откривања инфекције највећи број инфицираних особа је било у радном односу $(58,2 \%)$, међу којима је $72,1 \%$ са средњом стручном спремом, а $27,9 \%$ са завршеном високом школом. Незапослених је било $18,9 \%$, а деце 0,8\% (Графикони 9 и 10).

Графикон 9. Радни статус у моменту откривања инфекиије.

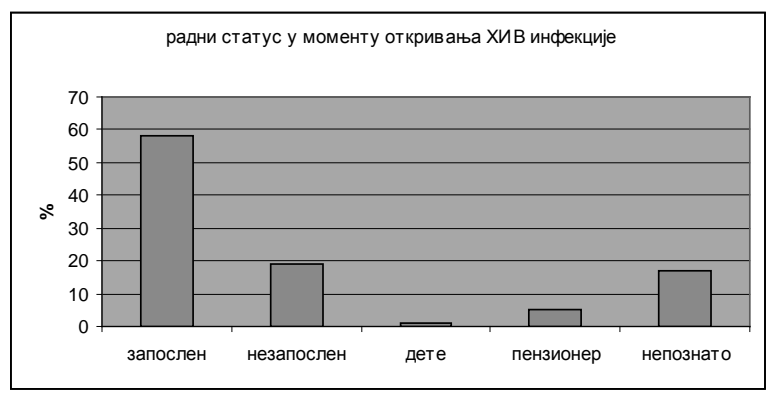

Графикон 10. Ниво образовања запослених у моменту откривања инфекције.

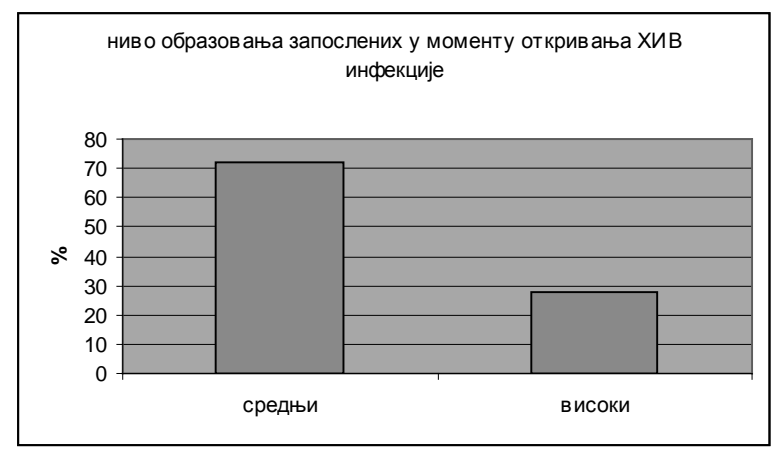




\section{ДИСКУСИЈА}

На подручју Београда од 2003. до 2012. године регистрована је ХИВ инфекција код 641 особе, обољење код 288 особа, a 185 особа је умрло са ХИВ-ом или од АИДС-а. У укупном броју инфицираних, оболелих и умрлих особа мушкарци су знатно заступљенији од жена $(83,9 \%, 76,7 \%$ и $76,2 \%$ ). Међу инфицираним и оболелим особама у посматраном периоду најчешћи начин трансмисије је ризично сексуално понашање међу хомо/бисексуалцима $(53,2 \%$ свих инфицираних, односно $35,4 \%$ оболелих ), док је међу особама умрлим са ХИВ-ом или од АИДС-а најодговорнија за инфекцију била интравенска употреба наркотика $(43,8 \%)$. Оно што карактерише епидемију ХИВ/АИДС у Београду у посматраном десетогодишњем периоду је касно откривање инфекција, односно откривање у фази развијеног АИДС-а. Најзаступљенија манифестација АИДС-а у посматраном периоду је био синдром кахексије (22,9\%), следи инфекција бацилом туберкулозе $(17,5 \%)$ и пнеумонија коју изазива Pneumocystis carinii $(15,4 \%)$.

У САД, крајем 2010. године, једна од 4 особе која је живела са ХИВ-ом је била жена. ${ }^{(3)}$ Осим региона субсахарске Африке, где жене чине $60 \%$ популације која живи са ХИВ-ом, у осталом делу света мушкарци су више погођени инфекцијом, што се слаже са односом полова у нашој земљи, односно у Београду. ${ }^{(4)}$

Иако су Старатегијом УНАИДС-а за период 2011-2015. године постављени циљеви за смањивање броја новоинфицираних ХИВ-ом, свет није на путу да смањи ХИВ трансмисију међу популацијом интравенских корисника дрога за 50\%, што потврђују новији подаци. ХИВ преваленција у овој популацији се креће од $5 \%$ у источној Европи до 28\% у Азији. Према подацима анализе пута трансмисије, интравенски корисници дрога и њихови сексуални партнери чине $68 \%$ свих нових ХИВ инфекција у Ирану, 40\% у земљама источне Европе и 36\% на Филипинима. Преваленција међу мушкарцима који имају секс с мушкарцима (МСM) лагано расте и достиже веома високе вредности последњих година. Преваленција у овој популацији у 2012. години износила је од $<1 \%$ до $57 \%$ (у Гвинеји). Поред тога, МСМ су често инфицирани веома млади. ${ }^{(2)}$ У Београду je МСМ најзаступљенија трансмисивна група у укупном броју ХИВ инфицираних и оболелих у посматраном периоду, док су ИВН најзаступљенији међу особама умрлим са ХИВ-ом или од АИДС-а.

Студије рађене у Италији и Новом Зеланду говоре о проблему касног откривања ХИВ инфекције, што је било присутно код више од 50\% испитаника. ${ }^{(5,6)}$ Према нашим подацима, касно откривање ХИВ инфекције варира од године до године и креће се од 12 до $48 \%$.

Студија која је испитивала учесталост опортунистичких инфекција код деце и адослесцената у ери високо активне антиретровирусне терапије утврдила је да су најучесталије биле бактеријска пнеумонија, херпес зостер, инфекције дерматофитама и орална кандидијаза. ${ }^{(7)}$ Студија рађена у Индији указује на туберкулозу и кандидијазу као најчешће опортунистичке инфекције. ${ }^{(8)}$ Када анализирамо клиничке манифестације АИДС-а међу оболелим особама у Београду, најзаступљеније су биле синдром кахексије $(22,9 \%)$, инфекција бацилом туберкулозе $(17,5 \%)$ и пнеумонија коју изазива Pneumocystis carinii $(15,4 \%)$. 


\section{ЗАКЉУЧАК}

На основу изнетог може се закључити да:

- Анализом епидемиолошке ситуације, поред варијација у броју новоткривених ХИВ инфекција, оболелих и умрлих особа са ХИВ-ом или од АИДС-а у посматраном периоду, уочава се све већи значај ризичног сексуалног, нарочито хомосексуалног понашања као пута преноса инфекције, док су интравенски корисници дрога далеко мање заступљени међу новооткривеним инфекцијама.

- ХИВ инфекција је најчешћа од 25 до 29 година и међу мушкарцима је ви- шеструко чешћа, што уз претходно наведен став о путу преноса инфекције, указује да превентивне програме треба планирати и учинити доступним млађој МСМ популацији.

- Континуирано истицати значај правовременог тестирања на ХИВ, што увек треба да буде праћено саветовањем, како би највећи број инфекција био откривен на време. Даљи надзор и праћење уз доступност терапије допринеће бољој прогнози инфекције сваког појединца. Поред тога, то доприноси спречавању даљег ширења инфекције.

\section{ЛИТЕРАТУРА}

1. Јевтовић Ђ, Анђелић С. и коаутори: ХИВ инфекција. Приручник за лекаре, 2007, стране 6. и 7.

2. UNAIDS: global report 2013.

3. CDC: Fact sheets, HIV among women.

4. WHO: Programmes, Gender, women and health, Gender inequalities and HIV, 2014.

5. d'Arminio Monforte A, Cozzi-Lepri A, Girardi E, Castagna A, Mussini C, Di Giambenedetto S, Galli M, Cassola G, Vullo V, Quiros-Roldan E, Lo Caputo S, Antinori A: Icona Foundation Study Group. Late presenters in new HIV diagnoses from an Italian cohort of HIV-infected patients: prevalence and clinical outcome. Antivir Ther. 2011; 16(7): 1103-12. doi: 10.3851/ IMP1883.

6. Dickson N, McAllister S, Sharples K, Paul C. Late presentation of HIV infection among adults in New Zealand: 2005-2010. HIV Med. 2012; 13(3): 182-9.

7. Gona P, Van Dyke RB, Williams PL, Dankner WM, Chernoff MC, Nachman SA, Seage GR: 3rd. Incidence of opportunistic and other infections in HIV-infected children in the HAART era. JAMA. 2006 Jul 19; 296(3): 292-300.

8. Saldanha D, Gupta N, Shenoy S, Saralaya V. Prevalence of opportunistic infections in AIDS patients in Mangalore, Karnataka. Trop Doct. 2008 Jul; 38(3): 172-3.

Контакт: Биљана Беговић Вуксановић, Градски завод за јавно здравље Београд, Булевар деспота Стефана 54a, тел. 0113230 038, 0112078 666; e-mail: biljana.begovic@zdravlje.org.rs 